\title{
Az adólikviditás kérdése és eszközei az adójogban
}

\author{
adólikviditás - rendkívüli vagyonadó - adóelöleg-fizetés - illetékek - \\ méltányosság - létminimum adómentessége
}

Az adórendszer kialakításánál alapvető fontosságú kérdés, hogy az adóztató hatalom milyen adótárgyakat jelöl ki, illetve milyen egyéb közterheket állapít meg. Az adóztató hatalomnak a tárgyak meghatározásánál széles mozgástere van: jövedelmek, vagyontárgyak, fogyasztási cikkek, személyek vagy éppen azok hiánya ${ }^{1}$ is lehet adótárgy. Lényeges továbbá az is, hogy milyen adómértékeket rögzít, milyen kivételeket, mentességeket, kedvezményeket állapít meg.

Fontos kérdés továbbá, hogy az adóztató hatalom hogyan alakítja ki a különböző adók arányát, milyen típusú adók érvényesítését részesíti előnyben és melyektől igyekszik tartózkodni. Az sem mellőzhető szempont, hogy az adóalanyok számára az adóteher hogyan jelenik meg, illetve az egyes adóalanyok között hogy oszlik meg. Az adóztató hatalom alapvető érdeke, hogy az adórendszert úgy alakítsa ki, hogy a lehető legkisebb áldozatok árán a lehető legmagasabb mértékű bevételre tehessen szert a közfeladatok finanszírozása céljából. Ugyanakkor az is hangsúlyos, hogy az adóalany adózási képessége ne sérüljön, illetve hogy a nem pénzben meglévő adótárgy ne vesszen el.

\section{Az adólikviditás fogalma}

Hogy e fenti általános kérdéseket tartalommal is meg lehessen tölteni, és az általánosságban felvázolt problémák kézzelfoghatóvá válhassanak, az adólikviditás fogalmát kell megvizsgálni. Hogy mit jelent ez a fogalom, milyen összetevői vannak, azt a közgazdaság-tudomány vizsgálja; a szakirodalomban viszonylag kevés szó esik az adólikviditásról, kiindulópontként a Balás Károly 1934-ben megjelent tanulmányában ${ }^{2}$ kidolgozott fogalom használható. A közgazdasági megközelítés alkalmazása mellett azonban lehetőség van arra is, hogy az adólikviditás a pénzügyi jogtudomány szempontjából is vizsgálat tárgyát képezze. A tanulmány e jogi vonatkozás feldolgozását, elméleti alapjainak megfogalmazását tüzte ki célul. Ennek

* Dr. Pfeffer Zsolt egyetemi adjunktus, Pécsi Tudományegyetem Állam- és Jogtudományi Kar Pénzügyi Jogi Tanszék, pffefer.zsolt@ajk.pte.hu.

1 A fejadók, illetve személyek hiány alatt például gyermektelenségi adó is érthető.

2 BALÁs Károly: Adólikviditás. Közgazdasági Szemle, 1934. 
érdekében leírja, hogy a tételes adójogban az adólikviditás kérdése hogyan érvényesülhet, hogyan jelenhet meg, melyek azok a tételes jogi rendelkezések, illetve joggyakorlati elemek, amelyek tekintetében az adólikviditás kérdésének befolyása, hatása egyáltalán felmerülhet. Végül pedig nevesíti azokat az eszközöket, amelyek az érvényre juttatását elösegíthetik. Elsődlegesen azokat az adónemeket (közterheket) vizsgálja, amelyeknél az adólikviditás kérdése hangsúlyos lehet, és amelyek - mind elméleti, mind gyakorlati szempontból - leginkább alkalmasak e terület problémáinak bemutatására.

A választott téma szoros kapcsolatban áll az adórendszer helyességének kérdésével: azzal, hogy egy jogállamban az adóztatás a lehető legnagyobb körültekintéssel és a lehető legkisebb „károkozással” valósulhasson meg. Azonban a megfelelő (az ideális) adórendszer vizsgálata kívül esik jelen tanulmány keretein, mivel a helyes adórendszer kialakítására vonatkozó szempontokról széles körü irodalom áll rendelkezésre. ${ }^{3}$

Az adólikviditás jelenti egyrészt, hogy az adótárgy (az adóforrás) biztositja a pénzszolgáltatási képességet, azaz képes az adóalany a terhére megállapított adót az esedékességig megfizetni az adótárgy (az adóforrás) teljes elveszítése vagy ellehetetlenitése nélkül, másrészt azt, hogy az adóalany a személyi és vagyoni körülményei alapján képes az adót megfizetni. Az adólikviditás vizsgálata azért indokolt különösen, mert például hiába rendelkezik az adóalany az adó tárgyával (például egy ingatlannal), vagy hiába van reménye az adóforráshoz való hozzájutásra (például a teljesített termékértékesítésről a számlát kiállította és megküldte a megrendelőnek), még nem feltétlenül rendelkezik azzal a pénzösszeggel, amely ahhoz szükséges, hogy az adófizetési kötelezettségének eleget tegyen.

Az adólikviditás két szinten vizsgálható: megkülönböztethető egyrészt az adóalany fizetőképessége, másrészt az adótárgy azon képessége, hogy biztosítani tudja az adóteher teljesítéséhez szükséges pénzösszeget (,,[m]indenekelött különbséget kell tennünk az adónem természetéböl és az adóalany egyéni és vagyoni körülményeiből folyó adólikviditás között" mány elsődleges feladatát, azonban szükséges néhány gondolat erejéig a személyi körülményekhez kapcsolódó likviditást is megvizsgálni, hiszen ezek a kérdések szoros összefüggésben állnak.

Az adólikviditás kérdése vizsgálható az adóztatás alapelveinek nézőpontjából is. Adam Smith alapvető követelményként (alapelvként) fogalmazta meg, az adózó olyan időben fizethesse meg az adót, amely a gazdasági viszonyainak természete szerint számára a legalkalmasabb. Itt is találkoznak az állam és az adózó érdekei, mert az állam is így jut hozzá legkönnyebben az adóbevételhez. ${ }^{5}$

Végül alapvető kérdésként fogalmazható meg az is, hogy az adóztató hatalom mit tehet annak érdekében, hogy az adólikviditás biztosítható legyen, milyen jogintéz-

3 Lásd például Szılovıcs Csaba: Az optimális adórendszer feltételeiről. In: Lentner Csaba (szerk.): Adózási pénzügytan és államháztartási gazdálkodás - Közpénzügyek és Államháztartástan II. NKE Szolgáltató Kft., Budapest, 2015, 281-310.

4 BalÁs (1934): i. m., 214.

5 Heller Farkas: Pénzügytan. Magyar Közgazdasági Társaság, Budapest, 1943, 140. 
mények szolgálhatnak arra, hogy védjék az adózókat, ugyanakkor lehetőség szerint biztosítható legyen a minél hatékonyabb adóztatás.

\section{Néhány alapvető közgazdasági-pénzügytani kérdés és jellemző}

Az adólikviditás kérdésének pénzügyi jogi vizsgálatát megelőzően szükség van arra, hogy e fogalom közgazdasági-pénzügytani elemei is bemutatásra kerüljenek az alábbiak szerint:

1. A pénzgazdálkodás uralomra jutására tekintettel értelemszerüen nem működik a korszerü államháztartásokban a természetbeni adóztatás. A középkor egyes időszakaiban például, amikor a pénzgazdálkodás nem volt elterjedt, a természetben történő adóztatás volt az alkalmazott és alkalmazható módszer, hiszen a gazdasági körülmények nem tették lehetővé (vagy csak rendkívüli nehézségek árán tudták volna lehetővé tenni), hogy az adó alanya a megtermelt javait, terményeit pénzzé tegye annak érdekében, hogy az adófizetési kötelezettségének pénzben tudjon eleget tenni. Ennek megfelelően alakult ki a terményadóztatás rendszere, amely elsősorban a tizedben és a kilencedben jelent meg Magyarországon. ${ }^{6}$ A korszerü pénzgazdálkodás hiányában az adóalanyoktól nem lehetett elvárni, hogy rendelkezzenek pénzszolgáltatási képességgel.

2. A pénzgazdálkodás elterjedését követően az adóztató hatalom számára a pénzben történő adóztatás vált kívánatossá, az adóalanyoknak tehát biztosítani kell (elő kell teremteni) a pénzben lerovandó adó megfizetéséhez szükséges összeget. Ilyen körülmények között mindenképpen vizsgálandó, hogy az adóztató hatalom hogyan jelöli ki az adótárgyakat, illetve milyen szabályok szerint határozza meg az adó alapját.

3. Az adóalanyok rendelkeznek egy maximális adólikviditással, de értelemszerüen az állam ezt nem használhatja ki (például jövedelemadó esetén a jövedelem $100 \%$-a is elvonható lenne elvileg, azonban az adótehernek e szint alatt kell lennie lényegesen).

4. Egy-egy adótárgy likviditása függhet a gazdasági és piaci körülményektől, a konjunktúraciklusok alakulásától. Ha például az adó tárgya termőföld, és a terményeknek biztos piaca van és megfelelő áron értékesíthetőek, akkor a termelö könynyen képes arra, hogy a föld hozadékát pénzre cserélje. Vagy ha például az építményadó tárgya az építmény, és az adóalany képes azt a piaci kereslet alapján bérbe adni, akkor képes az építményadó megfizetéséhez szükséges pénzt megszerezni, ha egyébként (egyéb forrásból) azzal nem rendelkezik. Viszont ha nem mutatkozik kereslet vagy csak kisebb mértékű kereslet mutatkozik az említettek iránt, akkor „megszünik vagy megcsökken ugyanazoknak az adóforrásoknak a likviditása

6 „Ezenkivül minden, bármely néven nevezendő szabad községben, valamint az udvarnoki és királynői községekben levő összes szántóvető és szőlőbirtokos jobbágyainktól (kivéve a falakkal bekeritett városokat) minden terményüknek és boruknak kilenczedét beszedetjük és a királyné asszony is be fogja szedetni. És a fönnt nevezett bárók és nemesek bármely birtokaikon levő minden szántóvető és szőllövel biró jobbágyoktól ezek minden terményének és borának kilenczed részét a maguk szükségére hasonlóképen hajtsák és szedjék be.” (1351. évi VI. törvénycikk) 
(a kellő időben a kellő mennyiségü adóösszeget szolgáltatni tudó ereje), amelyek jobb időszakokban és kedvező konjunktúrák között kielégitő mértékben mutatkoztak likvideknek". ${ }^{7}$

5. Az adórendszerrel szemben az egyik alapvető követelmény, hogy az arányos legyen, azaz az adóalanyok képességük szerint járuljanak hozzá a közös kiadások fedezéséhez. Az arányosság és az adólikviditás szoros kapcsolatban áll egymással, azonban két külön fogalomról van szó: lehet, hogy az adott közteher arányos, azonban az adóalany mégsem képes az adótárgy után az adót megfizetni akár az adótárgy jellege folytán, akár más okból kifolyólag, a személyi körülményei okán. Az adóztató hatalomnak az arányosságot szem előtt tartva úgy kell kialakítania a közterheket, hogy az adólikviditás is biztosított legyen.

\section{A rendkívüli vagyonadó (vagyondézsma, vagyonváltság) és az adólikviditás}

A történelemben nem volt példa nélküli az egyszeri, rendkívüli vagyonadó alkalmazása (ezt a rendkívüli, egyszeri vagyonadót szokták még vagyondézsmának, illetve vagyonváltságnak is nevezni).

Vagyonváltságra - mint rendkívüli adóra - a magyar pénzügyi jogtörténetben is található példa. A törvényhozás 1921-ben több törvénycikket is alkotott a vagyonváltságról. Az 1921. évi XV. törvénycikk a betétek, a folyószámla-követelések és a természetben elkülönítve őrzött készpénzletétek, továbbá a belföldi részvények és szövetkezeti üzletrészek, a külföldi pénznemek és a külföldi értékpapírok vagyonváltságáról, ${ }^{8}$ az 1921. évi XLV. törvénycikk az ingatlanok, a felszerelési tárgyak, az áruraktárak, az ipari üzemek és egyéb jószágok vagyonváltságáról, az 1921. évi XXVI. törvénycikk pedig a magyar államadósságokról és az azokat terhelő vagyonváltságról rendelkezett. A vagyonváltság alkalmazását a jogalkotó a következőkkel indokolta: „A trianoni békeszerződés folytán területének több mint kétharmadától és gazdasági segélyforrásainak legnagyobb részétől megfosztott Csonka-Magyarország pénzügyi terheinek könnyítése céljából és tekintettel azokra a törvényhozási intézkedésekre, amelyek egyéb vagyontárgyakat is vagyonváltság alá vontak, a törvényhozás ezekre az államadósságokra a következő rendelkezéseket állapítja meg..."

Surányi-Unger Tivadar a következőket fogalmazta meg a rendkívüli adó (vagyondézsma) tekintetében: „míg a többi adófajtát inkább rendes adóként szedjük, addig a vagyonadót inkább csak ily rendkívüli adóként szoktuk alkalmazni. Háborús időkben, rendkivülien nagy elemi csapások idején vagy különösen súlyos gazdasági válságokban fordulunk hozzá. Azért, mert ilyenkor a hirtelen megnövekedett közületi szükségletek kielégitéséhez szükséges eszközöket más módon egyáltalában nem tudjuk már elöteremteni. Az egyszeri vagyonadó lényege részleges vagyonelkobzás. Mértéke annál nagyobb lehet, minél egyoldalúbban hangsúlyozzuk a kiegyenlí-

7 BaLÁs (1934): i. m., 210.

8 A törvénycikk 1. §-a értelmében egyes pénzügyi intézményeknél elhelyezett betétek „1920. évi december 19-iki állaguk szerint vagyonváltság alá" estek. 
tő igazság elvét.”" Balás Károly pedig a következőket írta: „A rendkívüli vagyoni adók története szinte összeolvad úgyszolván minden állam gazdaságtörténetével. Szinte mindenütt találkozunk velük, mint kétségbeesett helyzetek, pénzügyi eröfeszitések, az adófizetőkön való eröszakoskodások, háborúk, a győző által különféle formában kirótt hadisarcok fedezetének stb. indokából elrendelt szolgáltatásokkal. Itt föleg az úgynevezett vagyondézsmák érdekelnek közelebbröl, amelyek a világháborút követő időszakban több országban a pénzügyi eröfeszítések jegyében bukkantak elö. 'Egyszeri' vagyoni adóknak (einmalige Vermögensabgaben) is nevezik öket, habár gyakran meg is ismétlődnek különböző elnevezések alatt. Jellemző sajátságú méreteik rendkivüli voltában is megnyilatkoztatik, úgy hogy rendszerint csak a törzsvagyon s így az adóforrások megcsonkitásával fedezhetök." 10

Az egyszeri, rendkívüli jellegü vagyonadó gondolata a 2008-as pénzügyi-gazdasági válság kialakulását és kiszélesedését követően időröl időre felmerül mint a rendkívül magas államadóssági szintek kezelésének egyik lehetséges eszköze. Így például a Deutsche Bundesbank 2014 januárjában elemzést"11 készített az alkalmazhatóságról, de a 10\%-os, nettó vagyonra kivetendő adó ötletét az IMF is felvetette 2013-ban. ${ }^{12}$

\section{Az adólikviditás jellemzői, problémái}

Az általános elméleti-történeti alapok leírását követően szükséges a tanulmány tárgya szempontjából jelentős elemzések elvégzése. Az ilyen típusú vagyonadók azért különösen érdekesek az adólikviditás szempontjából, mert a vagyon nemcsak pénzösszegből, hanem egyéb ingatlanokból, ingókból és vagyoni értékű jogokból is állhat. Ha az adóalany nem rendelkezik elegendő pénzzel, hogy a vagyon meghatározott százalékát pénzösszegben megfizesse, akkor kénytelen a nem likvid adótárgy sérelme (elidegenítése) útján biztosítani az adó megfizetéséhez szükséges pénzösszeget - ahogyan Heller Farkas is rámutatott: kénytelen a vagyona egy részét pénzzé tenni -, vagy másik megoldásként a kölcsön igénybevétele (valamilyen hitelmúvelet alkalmazása) merülhet fel. Ha tehát az adóztató hatalom nem akarja az adóalanyok széles körét súlyos pénzügyi körülmények közé szorítani, illetve a vagyonuk egy részétöl - és ezzel párhuzamosan az adótárgyaktól őket - megfosztani, akkor tekintetbe kell vennie az adólikviditás jellemzőit, problémáit is az egyéb jogi aggályokon kívül.

Az adólikviditás szempontjából az egyszeri, rendkívüli vagyonadók tekintetében a felvázoltak alapján a következő alapvető jellemzőket, kockázatokat, kérdéseket kell mérlegelni, megvizsgálni:

9 SuRÁnyi-Unger Tivadar: Magyar Nemzetgazdaság és Pénzügy. Dunántúl Pécsi Egyetemi Könyvkiadó és Nyomda R.-T., Budapest, 1936, 375.

10 BaLÁs Károly: Pénzügytan. Királyi Magyar Egyetemi Nyomda, Budapest, 1935, 363-364. Lásd még TótH János: A lakosság adói. Közgazdasági és Jogi Könyvkiadó, Budapest, 1977, 185-186.

11 http://www.bundesbank.de/Redaktion/DE/Standardartikel/Themen/2014_01_28_monatsbericht_kasten. html (2014. 06. 16.).

12 http://www.imf.org/external/pubs/ft/fm/2013/02/pdf/fm1302.pdf\#page=59, (2014. 06. 16.), 49. 
1. Az adó tárgyának meghatározása. Az adóztató hatalom döntheti el, hogy a rendkívüli vagyonadót milyen elemekre veti ki: pénzösszegre (jövedelemre), ingatlanokra, ingókra, vagyoni értékü jogokra vagy éppen a pénzügyi intézményeknél elhelyezett betétekre, megtakarításokra. Az adóztató hatalom akkor tudja eredményesen érvényesíteni a rendkívüli vagyonadót, ha olyan adótárgyakat jelöl ki, amelyek tulajdonlása közhiteles nyilvántartásokon alapul, illetve amelyek az adózótól független szervezetek kontrollja alatt állnak. Így elsősorban az ingatlanok, meghatározott ingók (például gépjármüvek), valamint a pénzügyi intézményeknél meglévő betétek, megtakarítások alkalmasak adótárgynak. Az ingatlanok és az ingók mint adótárgyak nem likvidek, a pénzben kifejezendő és megfizetendő adó megfizetése az adóalanyok részéröl komoly problémákat eredményezhet.

2. Az adó alapjának meghatározása. Az adó alapjának meghatározása azért különösen jelentős kérdés az ingatlanok és az ingók adóztatása esetében, mert ha érték alapján történik az adó kivetése, akkor annak problémájaként merül fel, hogy miként határozandó meg a vagyon értéke, a becslés elvégzése kinek a feladata (önadózás útján valósulna meg vagy pedig kivetéssel, kiszabással).

3. Alkotmányjogi vonatkozások. A rendkívüli vagyonadó voltaképpen részleges vagyonelkobzás: a pénzben meglévő vagyon egy részét az adóztató hatalom elvonja, a nem pénzben lévő vagyon után pedig az adózó szintén köteles az adó összegét pénzben biztosítani. Ha nem rendelkezik az adó megfizetéséhez szükséges pénzzel, akkor az adótárgyak értékesítése (vagy kölcsön) útján kell az adó összegét előteremteni. Bármelyik megoldás is jön szóba, mindenképpen felmerül a tulajdonhoz való alapjog vizsgálatának szükségessége. Megjegyzendő, hogy elképzelhetőek olyan rendkívüli helyzetek, amelyek igazolhatják az ilyen típusú adó alkalmazhatóságát.

A fentiekből következően az adózókat egy rendkívüli vagyonadó alkalmazására vonatkozó jogalkotói döntés különösen érzékenyen érintheti, hiszen a nem pénzben meglévő vagyonelemek után hiányozhat a pénzszolgáltatási képesség. Így alapvető kérdés a helyes arány meghatározása, továbbá a megfelelő adótárgy kiválasztása, azazhogy mennyiben jelöl ki az adóztató hatalom likvid vagyonelemeket. Az adóztató hatalomnak a kevésbé likvid adótárgyak felé kell ilyenkor elmozdulnia, hiszen, feltéve, hogy nincsenek rendkívüli gazdasági (háborús, illetve háború utáni) körülmények és a jogállami feltételek adottak, az adó alanyai a likvid adótárgyakat elrejthetik, elvonhatják az adó alól (például a pénzügyi intézményekben, számlákon elhelyezett pénzeszközöket magukhoz veszik), viszont a kevésbé likvid vagyonelemek - különösen az ingatlanok - értékesítése körülményes, költséges és időigényes. A számlák hirtelen zárolása és adott értéken történő egyszeri megadóztatása pedig összeegyeztethetetlen lehet a jogállami követelményekkel, mivel a közterheket megállapító jogszabályok alkalmazására való felkészülési időtartam biztosítása nem mellőzhető. Radikális megoldás hiányában azonban a hatékonyság kérdőjelezhető meg. (Hiszen kellő időtartam esetében elegendő idő állhat rendelkezésre a vagyon elvonására, elrejtésére.) 


\section{A méltányosság és a fizetési könnyítések rendszere}

A jogalkotó is elismer olyan élethelyzeteket, amikor az adóalany hozzájutott az adó tárgyához (az adó tárgyát képező értékhez), azonban valamilyen oknál fogva mégsem képes az adó összegének megfizetésére, vagy a megfizetés a megélhetést ellehetetlenítené. A méltányosság követelményével összhangban az ilyen esetekre szabályozzák az átmeneti fizetési nehézségek áthidalására a fizetési könnyítések rendszerét; az adóhatóság az adózó kérelmére, az adózó által előadottak és az azok alátámasztására benyújtott bizonyítékok alapján mérlegel, és ha elfogadható az adózói indokolás, akkor engedélyezhet fizetési könnyítést (részletfizetést, fizetési halasztást). Emellett alkalmazható eszköz bizonyos esetekben a tartozás mérséklése, illetve elengedése is.

Mariska Vilmos különbséget tett az átmeneti és állandó fizetési képtelenség között. Megfogalmazta, hogy „[a]z oly tartozás, mely az adóköteles fizetési képességének hiánya miatt vált hátralékká, jogosan nem lehet az adóvégrehajtás tárgya, mert a legszigorúbb adóbehajtás sem facsarhat ki többet, mint amennyi van. Idöleges fizetési képtelenség esetében fizetési halasztás engedélyezendő, végleges és teljes képtelenség esetében az adótartozás törlése rendelendő el. Ha az adóbehajtás az adókötelest minden vagyonától fosztaná meg, több évre terjedő részletenkénti törlesztését kell megengedni. Az oly végrehajtás, mely az adózót földönfutóvá teszi, nem csak embertelen eljárás, de az államkincstárra is kárt hoz, mert végkép megfosztja a polgárt adóerejétől és csökkenti az adózók számát. Söt a minden kiméletet nélkülöző behajtás még a közkiadásokat is szaporithatja, mert ha az adóvégrehajtó ma az utolsó falatot szedi el a polgártól, holnap a község, illetöleg az állam talán segélyt kénytelen nyujtani az éhező koldusnak [...] Ellenben azok irányában, kik nem fizetési képesség, hanem fizetési akarat hiánya miatt maradtak hátralékban, kellő szigorral és minden halogatás nélkül járjon el az adóigazgatás.”13

A felmerülő problémák kezelése a méltányosságon is túlmutat, hiszen az adóztató hatalom érdeke is, hogy az adóalany jövőbeli adózási képessége a feltétel nélküli végrehajtás folytán ne szenvedjen tartós károsodást, illetve ne semmisüljön meg. Ha azonban van olyan vagyontárgy, amely kevésbé likvid, ugyanakkor a megélhetéshez nem nélkülözhetetlen, elvárható, hogy az adózó a pénzszolgáltatási képességét azáltal állitsa helyre, hogy a kérdéses vagyontárgyat értékesiti. Így például a Kúria egyik ítéletében megfogalmazta, hogy az adóhatóság „okszerü bizonyitékértékeléssel vonta le azt a ténybeli és jogkövetkeztetését, mely szerint a felperesnek van olyan vagyontárgya, amely nem nélkülözhetetlen a megélhetéséhez, és fedezetet biztosít a tartozás megfizetésére" ${ }^{14} \mathrm{Az}$ alapul fekvö ügyben az adóhatóság elutasította az adózó illetékre vonatkozó részletfizetési kérelmét azon az alapon, hogy „,nem állapitható meg a megélhetés veszélyeztetése ott, ahol a kérelmező vagy a vele közös háztartásban élő közeli hozzátartozó a megélhetéshez nem nélkülözhetetlen vagyonnal rendelkezik (balatoni nyaraló résztulajdon, személygépkocsi),

13 Mariska Vilmos: Az államgazdaságtan (Pénzügytan) kézikönyve. Franklin Társulat Magyar Irodalmi Intézet és Könyvnyomda, Budapest, 1885, 141-142.

14 A Kúria Kfv.V.35.246/2012/4. számú ítélete. 
melyek értéke többszörösen fedezetet nyújt az adómérséklési kérelemmel érintett tartozásból még fennálló tartozás [...] egy összegben való megfizetésére a megélhetés súlyos veszélyeztetettsége nélkül is, ezért a tartozás mérséklésére, elengedésére sincs jogszabályi lehetőség."

\section{Az adóelőlegeztetés}

A magyar adórendszerben több adónemnél - így különösen a személyi jövedelemadónál, a társasági adónál vagy éppen az egyszerüsített vállalkozói adónál ismert az adóelőleg-fizetési kötelezettség megállapítása annak érdekében, hogy az államháztartás bevételei folyamatosak legyenek. Ezeket az adókat évente kell megfizetni, azonban különböző módszerek alapján - tényszámokra alapítva, bázisalapon vagy éppen elöre prognosztizált módon - adóelőleget kell fizetni. Az adóelőleg mértékét a jogalkotó úgy köteles meghatározni, hogy az adózók széles köre ne kerüljön túlfizetésbe rendszeresen. Az Alkotmánybíróság például megfogalmazta egyik döntésében, hogy ha „az elöleg adókulcsa olymódon kerül megállapításra, hogy azzal az adózók teljes körére és teljes bizonyossággal megállapítható lesz az adó túlfizetése, akkor az már túllép a megengedhető átmeneti aránytalanságon, lényegét tekintve az állam javára előirt kényszerhitelnyújtás a jogosult részéről". ${ }^{15}$

Az említett adónemeknél az adóalany által megszerzett vagyoni érték (jövedelem) képezi az adó tárgyát, amely az egyik leglikvidebb adótárgynak tekinthető, hiszen az adó összege egyszerű művelettel a megszerzett összegből elkülöníthető és megfizethető. Mindez azonban csak akkor igaz, ha ez az elkülönítés és megfizetés a pénz megszerzésével egyidejüleg megtörténik, ugyanis ellenkező esetben fennáll az esélye annak, hogy az adózó az adófizetés időpontjáig (az esedékesség időpontjáig) nem őrzi meg elkülönített módon az adó összegét, hanem azt másra fordítja, ennek megfelelően gondoskodni szükséges az azonnali elkülönítésröl, amely az adólevonás kötelezettségében jelenik meg. Így az adóelőlegeztetés nemcsak az államháztartás bevételeinek folyamatossága érdekében alkalmazható, hanem abból a célból is, hogy az adótárgy - a jövedelem - megőrizze likviditását. Ha ugyanis az elöleg levonásra kerül egy, az adó alanyától független személytől (munkáltatótól, kifizetőtől), akkor jelentősen csökken annak a kockázata, hogy az adóalany végül mégsem képes egy nagyobb összeget megfizetni az adó esedékességekor, az adólevonás viszont mentesíti az adóalanyt az adólikviditás tudatos tervezésének kötelezettsége és felelőssége alól. Éppen ezért fontos, hogy a személyi jövedelemadóról szóló törvény az adó alanyán - azaz a jövedelmet realizáló személyen - kívül milyen további alanyokra terjeszti ki a hatályát oly módon, hogy levonási kötelezettséget állapít meg a terhükre (például a munkáltatókra nézve a munkaviszonyból származó jövedelem esetében vagy a kifizetőkre nézve a bérleti díjak esetében). Megjegyzendő, hogy levonási kötelezettség nemcsak adóelöleghez kapcsolódhat, hanem magához az adóhoz is.

15 26/2004. (VII. 7.) AB határozat, ABH 2004, 398. 


\section{Az adólikviditás kérdése a vagyoni típusú helyi adók esetében}

Különösen hangsúlyos az adólikviditás kérdése azon adók esetében, amelyek a nem pénzben meglévő vagyont terhelik. A magyar adórendszerben is létezik vagyonadóztatás,$^{16}$ viszont elsősorban nem központi adóként, hanem helyi (vagy éppen települési) adókként alkalmazhatóak különböző vagyonelemeket terhelő adók. A helyi adókról szóló 1990. évi C. törvény (Htv.) lehetővé teszi egyrészt az építmények, másrészt a telkek adóztatását a települési önkormányzatok számára, ezen túlmenően a 2015-töl bevezethető, ún. települési adók is kínálnak lehetőséget különböző vagyonelemek (így például föld, nádas, állatok) adóztatására.

A vagyont terhelő adók esetében különös jelentősége van annak, hogy a nem likvid tárgyak képesek-e biztosítani a pénzbeli szolgáltatás képességét (azaz rendelkezésre áll-e elegendő hozadék, amelyböl ez az összeg kifizethető). Különösen hangsúlyos ebből adódóan, hogy a jogalkotó milyen eszközökkel tudja biztosítani az adólikviditást. Ezek az eszközök a következők lehetnek:

1. Az adómegállapítási jog kereteinek rögzítése (adómaximumok meghatározása). Ha a központi jogalkotás (törvényhozás) adóztatási joggal ruház fel töle független szervezeteket, akkor mérlegelni szükséges ezen adóztatási jog határainak megvonását, garanciák közé szorítását is. Különösen fontos így az egyes helyi adók esetében az, hogy a törvényhozás határozza meg az adók lehetséges fajtáit, az adók alanyait, tárgyait, az alapot, az adó felső határát (az adómaximumokat), illetve azokat a mentességi, kedvezményi tényállásokat, amelyek legalább megilletik az adó alanyait. ${ }^{17} \mathrm{~A}$ helyi adóztatáshoz kapcsolódó garanciális követelmények szükségessége tekintetében Paul Leroy-Beaulieu megfogalmazta, hogy „[a] legtöbb európai országban abból a szempontból indultak ki, hogy korlátozzák a helyi hatóságokat adókivetési jogukban általában, vagy legalább azon tárgyakban, melyeket adó alá vonhatnak. Az állam financiális ellenörzése a helyi adókkal szemben, a legnagyobb mérvben igazolt és üdvös. Illö, hogy az állam, mely a nemzet közérdekeit képviseli, mely azonkívül felvilágosodottabb, részrehajlatlanabb és elörelátóbb; illö, mondjuk, hogy az állam felügyelhessen arra, hogy az ország egy része se váljék képtelenné az állami terhek viselésére."18

Az adómegállapítási jog - és így az adólikviditás biztosításának kérdése - különösen fontos lehet a települési önkormányzatok által bevezethetö települési adók esetében, amelyekhez kapcsolódóan - a helyi adókra vonatkozó részletes szabályozással ellentétben - a törvényhozás pusztán néhány alapvető korlátozás törvényi szintü rögzítését tartotta szükségesnek, egyebekben az önkormányzatok hatáskörébe utalta az adó fajtájának „kitalálását” (és így az alanyok, az adótárgyak stb. meghatározását). A Kúria rámutatott arra, hogy a helyi adók tényállási elemeinek szabályozása kiszámítható, viszont a települési adók esetében - néhány alapvető

16 A vagyon mobilizálódásához kapcsolódó (azaz dinamikus) adónak tekinthetőek a szerzést terhelő illetékek a magyar rendszerben (öröklési, ajándékozási és visszterhes vagyonátruházási illeték).

17 A kérdésröl lásd részletesebben PFEFFER Zsolt: A nullum tributum sine lege elv. Jogtudományi Közlöny, 2015/11.

18 Leroy-Beaulieu, Paul: Pénzügytan. A Magyar Tudományos Akadémia Könyvkiadó-Vállalata, Budapest, 1880, II. kötet, 424-425. 
korlátozás kivételével - a jogalkotó a törvényi kereteket (az adótényállás egyéb elemeit) nem határozta meg, hiányoznak a Htv.-böl azon anyagi jogi garanciák, amelyek biztosítanák az Alaptörvény XXX. cikkében foglaltak teljesülését. ${ }^{19}$

Az adóztató önkormányzatoknak így különösen fontos azon adótárgyak és adómértékek megtalálása, amelyek biztosítják az Alaptörvényben foglalt rendelkezések érvényesülését, illetve mindezeknek megfelelően az adólikviditást.

2. Az adófelfüggesztés. Az adófelfüggesztés azt jelenti, hogy az építményadót (vagy a magánszemély kommunális adóját) a kérelmezőnek - az adóhatóság által elfogadott időtartam alatt - nem kell megfizetnie, ha azonban a felfüggesztés megszünik, akkor az elmaradt adót kamattal terhelve meg kell fizesse. A törvény meghatározza az alanyok körénél, hogy 65 év felettiek vagy megváltozott munkaképességüek kérhetik az adófelfüggesztést. A jogszabályi rendelkezések alapján megállapítható, hogy a jogalkotó elsősorban olyan csoportok esetében teszi lehetővé az adófelfüggesztés alkalmazását, akikröl alaposan feltehető, hogy nem rendelkeznek az adó megfizetéséhez szükséges pénzszolgáltató képességgel, figyelemmel arra, hogy az adó tárgya - az építmény - kevésbé likvid az adózás szempontjából, és e személyek vagyoni, jövedelmi viszonyait illetően nem lehet jelentős mértékű pozitív elörelépésre számítani (azazhogy pénzszolgáltató képességük növekedni fog), így az esetükben sok esetben a hagyományos fizetési könnyítések (például részletfizetés, halasztás) alkalmazása sem jelenthetne megoldást. Éppen ezért biztosított ezen alanyok számára az adófelfüggesztés alkalmazásának lehetősége azon építmény esetében, amelyben életvitelszerüen élnek.

3. Általános követelmények érvényesítése. A Htv. az adómegállapítási jog keretében rögzíti, hogy az önkormányzat joga arra terjed ki, hogy az adó mértékét a helyi sajátosságokhoz, az önkormányzat gazdálkodási követelményeihez és az adóalanyok teherviselő képességéhez igazodóan - az adó felső határára, illetve az adómaximumra meghatározott törvényi elöírások keretei között - állapítsa meg. ${ }^{20}$

$A z$ idézett rendelkezésben szerepel a teherviselő képesség mint figyelembe veendő szempont. Az önkormányzat az általa meghatározandó adómértéken kívül konkretizálhatja az adómentességekre, illetve adókedvezményekre vonatkozó rendelkezésekben a teherviselö képességre vonatkozó általános követelményt.

A teherviselő képesség különösen hangsúlyos a vagyoni típusú adók esetében, hiszen ilyen esetben külön kell gondoskodnia az adóalanynak a fizetendő adó öszszegének megszerzéséről. Ez azoknál az ingatlanoknál jelenthet problémát, amelyeket az adóalany saját maga használ (például életvitelszerüen ott él vagy a telket saját maga hasznosítja müvelés útján). Viszont a további, egyéb ingatlanok esetében a hozadék (például bérleti dij) jelentheti az adólikviditás alapját. Ha viszont az önkormányzat nem biztosít megfelelő kedvezményeket, mentességeket, akkor a rendelete jogellenesnek minősíthető. Az Alkotmánybíróság rámutatott, hogy a tételes adó (például a telek alapterülete után megállapított adó) korlátozottabb lehetőséget kínál az értékarányos adóztatásra, és így a Htv. rendelkezéseinek betartása mellett is elöfordulhat, hogy sérti az arányos közteherviselés követelményét.

\footnotetext{
19 A Kúria Köf.5.035/2015/4. számú határozata.

20 Htv. 6. § c) pont.
} 
Ez abban az esetben fordulhat elö, ha az önkormányzati rendelet nem állapít meg olyan mentességi, kedvezményi eseteket, amelyek tükröznék a helyi sajátosságokat, az értékben fennálló különbségeket, valamint az adóalanyok teherviselö képességének mérlegelését. ${ }^{21}$

\section{Az illetékek és adólikviditás kérdése}

Az adólikviditás kérdésének vizsgálata szempontjából az illetékeket két nagy csoportra lehet osztani: a tervezhető vagyonátszállásokat terhelő illetékekre és a nem (vagy kevésbé) tervezhető vagyonátszállásokat terhelö illetékekre (hogy valamely adórendszer a vagyonátszállást adóval és nem illetékkel terheli, az az adólikviditás szempontjából irreleváns).

Az adólikviditás különösen azon esetekben bír különös jelentőséggel, amikor a vagyonátszállás váratlanul történik meg: öröklés esetében az örökség megnyílta általában nem látható előre, illetve egzakt módon nem tervezhető. Így ha hirtelen, előre nem várt módon következik be az öröklés, akkor különösen hangsúlyossá válhat a szerző személy (az örökös, hagyományos, kötelesrészre jogosult stb.) likviditásának megléte. Ez alatt elsődlegesen azokat az eseteket értjük, ha a hagyatékban elsősorban nem likvid vagyonelemek vannak, nem pedig pénz, illetve ha a hagyatékban lévő vagyontárgyak értékesítési lehetősége korlátozott. Ugyancsak alapvetően érintheti az adólikviditás kérdését, ha a hagyatékban kintlévőségek is vannak (amelyek csak később érvényesíthetőek vagy éppen nem érvényesíthetőek). Ezen említett példák felhasználásával célszerü az illetékek és az adólikviditás kapcsolatát áttekinteni, illetve tárgyalni.

1. A kiskorú örökös öröklése. Az illetékekröl szóló 1990. évi C. törvény (Itv.) külön nevesít olyan kedvezményt, amely öröklési illeték esetében a kiskorú által megszerzett örökség tekintetében érvényesíthető. A kedvezmény lényege, hogy késedelmi pótlékmentesen fizetheti meg a kiskorú örökös a nagykorúvává válásától számított két évig az illetéket, ha pedig korábban teljesít, akkor kedvezményben részesül. Mindez azon az elgondoláson is alapul, hogy a kiskorúak jellemzően nem rendelkeznek önálló jövedelemmel és ebből adódóan jelentősebb készpénzzel, az örökölt vagyon elidegenítése - az adótárgy pénzzé tétele - a kiszabott illeték megfizetése érdekében pedig a cselekvőképesség hiánya folytán akadályokba ütközhet. A jogalkotó feltételezi a pénzszolgáltatási képesség korlátozott voltát, illetve hiányát, hiszen lehetséges, hogy a hagyatékban az illetékfizetési kötelezettség teljesítéséhez elegendő pénz is található, azonban ez nem törvényszerü. A jogalkotó ezt a körülményt vizsgálni nem kívánja, a kedvezmény a kiskorú örököst a törvény erejénél fogva megilleti. A jogalkotó tehát - e kedvezmény útján - megadja a lehetőséget a kiskorú örökösnek, hogy ha egyébként nem képes megfizetni az illetéket, akkor legyen elegendő ideje fizetőképessé válni (vagyis adólikviditásra szert tenni). Ha pedig mégis rendelkezik elegendő pénzzel (adólikviditással), és a határidő lejártát megelőzően megfizeti az illetéket, akkor kedvezményre jogosult (a korábbi teljesítés éveinek számához igazodva). 
2. A kintlévőség öröklése. Az is elöfordulhat, hogy a hagyatékban az örökhagyót megillető követelés is helyet kap, és e követelés joga ugyancsak átszáll az örökösre. llyen esetben is fennáll az illetékfizetési kötelezettség. Egy esetben az örökös arra is hivatkozott az adóhatósági határozatot felülvizsgáló bírósági eljárásban, hogy az általa megörökölt követelés (az örökhagyó irányába fennálló tartozás) bizonytalan, mert végrehajtás van folyamatban az érvényesítés iránt, azonban nincs az adósnak végrehajtás alá vonható vagyontárgya, így a behajthatatlanságot vélelmezni kell, ebből adódóan illetékkiszabás alapjául az ilyen követelés nem szolgálhat. A Kúria azonban nem fogadta el az érvelését, ugyanis az indokolása szerint nincs jelentösége annak, hogy az örökös a megszerzett követelés alapján ténylegesen mikor jut hozzá a pénzösszeghez, továbbá nem is vitatta a követelés összegét, továbbá a követelés behajthatatlanságát nem tudta igazolni, méltányosság gyakorlására pedig nem volt jogszabályi lehetőség. Ugyanakkor a Kúria is rögzítette, hogy az Itv. 80 . § (1) bekezdés a) pontja alapján lehetőség van a kiszabott, de még meg nem fizetett illeték törlésére, ha olyan körülmény áll be, amely az örökség értékét az öröklés megnyíltának idejére visszaható módon csökkenti. ${ }^{22}$

3. A visszterhes vagyonátruházási illeték kérdése. A visszterhes vagyonátruházáshoz kapcsolódóan az adólikviditás kérdése nem merülhet fel azon az alapon, hogy az a vételárhoz kapcsolódik, mivel a vevő képes elöre kalkulálni a vagyonszerzési illeték összegét. Tehát elviekben tartózkodhat a vásárlástól, ha tudja, hogy nem rendelkezik az illeték összegével is a vételáron felül.

Az adólikviditás tehát fő szabály szerint biztositható a visszterhes szerzéshez kapcsolódó illetékek esetében, azonban ennek a gazdasági hatásai kétségesek lehetnek. David Ricardo például rámutatott arra, hogy a vagyonátruházást terhelő adók meggátolják, hogy a nemzeti tőke a közösség szempontjából legelönyösebben oszoljon el. „Az általános jólét érdekében nem lehet eléggé megkönnyíteni mindenféle tulajdon átszállását és cseréjét, mert valószínü, hogy ezen az úton mindenfajta töke azoknak a kezébe jut, akik legjobban tudják azt használni." Say álláspontját is idézte: „Miért akarja valaki eladni a földjét? Azért, mert jobb üzletre van kilátása, amelynél tőkéje többet fog hozni. Miért akarja másvalaki megvenni ugyanezt a földet? Azért, mert így akarja hasznosítani tökéjét, amely túl keveset hoz, amely gyümölcsözetlenül hever, vagy amelynek ilyen befektetését fejlődésre képesnek gondolja. Ez a csere az összjövedelmet növelni fogja, miután szaporitja a felek jövedelmeit. De ha olyan rengeteg az adó, hogy a cserének útját állja, akkor a nemzeti jövedelem emelkedésének akadálya lesz." Végül Ricardo megfogalmazta, hogy „[e]zeket az adókat azonban könnyü behajtani. És sokan azt hiszik, hogy ez a körülmény bizonyos kárpótlást nyújt káros hatásaikért."23

22 A Kúria Kfv.V.35.006/2013/5. számú itélete.

23 RICARDO, David: A közgazdaság és adózás alapelvei. Szeged Városi Nyomda és Könyvkiadó Részvénytársaság, Budapest, 1940, 113-114. 


\section{A vagyoni érték tényleges megszerzésének kérdése}

Ahogyan arról korábban volt szó, az egyik leglikvidebb adótárgy (adóforrás) a pénzben megszerzett jövedelem; a likviditása biztosítható azáltal, hogy a megszerzett értéktöl azonnal el kell különíteni az adó összegét (elöleg formájában és levonás alkalmazásával).

Ugyanakkor az is rendkívül lényeges, hogy a vagyoni értékhez (az adó alapját képező összeghez) ténylegesen is hozzájusson az adóalany. Azoknál az adónemeknél ugyanis, amelyeknél elválhat egymástól az adófizetési kötelezettség beálta és az adó alapját képező bevétel megszerzése, a likviditás sérülhet, illetve teljes mértékben hiányozhat. Így ha például a felek halasztott fizetésben (fizetési határidőben) állapodnak meg, a számla kiállításra kerül, ugyanakkor a számla összegét a kötelezett csak később vagy egyáltalán nem fizeti meg, a likviditás jelentős mértékben sérül, illetve meg is szünhet. Két adónemet lehet példaként ebben a körben megvizsgálni: egyrészt az általános forgalmi adót (áfa), másrészt pedig az egyszerüsített vállalkozói adót (eva).

Az általános forgalmi adóról szóló 2007. évi CXXVII. törvény (Áfatv.) fő szabálya szerint az adó alanya az, aki a terméket értékesíti, illetve a szolgáltatást nyúijja (a terméket importálja). Ez azt jelenti, hogy az adóalany a termék (szolgáltatás) árát megnöveli az általános forgalmi adóval, az adófizetési kötelezettséget pedig annak a ténynek a bekövetkezése keletkezteti, amellyel az adóztatandó ügylet tényállásszerüen megvalósul. ${ }^{24}$ Ebböl az is következik, hogy ha megtörtént az egyik fél részéröl a teljesítés, arról a számlát kiállította és megküldte a vásárlónak/megrendelönek, viszont a másik fél nem fizeti meg az ellenértéket (azzal jelentős késedelembe esik), akkor huzamosabb ideig meg kell elölegeznie a fizetendő áfát (fokozott problémát jelenthet ez olyan szektorokban, ahol a lánc- és körbetartozások különösen jellemzőek és különösen sok nehézséget okoznak). Így ebben a körben is irányadó lehet az Alkotmánybíróság azon megállapítása, amely szerint az üzleti partnerek fizetöképességének előzetes felmérése valamennyi vállalkozás esetében a vállalkozások üzleti kockázatát képezi. A jogalkotó az adójogszabály megalkotása során dönthet úgy, hogy ezt az üzleti kockázatot részben átvállalja az adóalanyoktól (vállalkozásoktól), de ez értelemszerűen nem kötelező. ${ }^{25}$ Ugyancsak megemlíthető az a bírósági ítélet, amely szerint az adó megfizetésének kötelezettsége szempontjából nem bír jelentőséggel „az üzleti partner magatartása, fizetési készségének hiánya, a követelés behajtására tett intézkedések elhúzódása vagy eredménytelensége, mivel ezek a vállalkozási, gazdasági, üzleti tevékenységgel együtt járó köztudomású kockázati tényezők. A számla szerinti ellenérték meg nem fizetése kapcsán felmerülő elszámolási kérdések kizárólag polgári jogi természetüek, és a számlakibocsátó adófizetési kötelezettsége szempontjából irrelevánsak." ${ }^{26}$

A fordított áfafizetési kötelezettség a fent említett problémákra jelenthet megoldást, hiszen ebben az esetben az adót a termék beszerzője, a szolgáltatás igénybe

\footnotetext{
24 Áfatv. 55. § (1) bekezdése.

25 969/E/2006. AB határozat, ABH 2007, 2071.

26 A Kúria Kfv.l.35.521/2006/9. számú ítélete.
} 
vevője fizeti, nem pedig az, aki a terméket értékesíti, illetve a szolgáltatást nyújtja. (Ezen túlmenően a fordított áfafizetés a csalások visszaszorításának is fontos eszköze lehet, így ezért terjesztette ki a jogalkotó egyes mezőgazdasági termékekre is a fordított adózást.) A jogalkotó az Áfatv.-ben kifejezetten felsorolja ${ }^{27}$ azokat az eseteket (árukat, szolgáltatásokat), amelyek esetében az adó viselése a fö szabálytól eltér (nevesítve az alkalmazhatóság egyéb feltételeit is), eltérő kifejezett szabály hiányában pedig a fő szabály irányadó.

További lehetséges megoldás a fenti problémák kiküszöbölésére az ún. pénzforgalmi elszámolásra vonatkozó szabályok alkalmazása, amely szabályok bevezetésére 2012-ben került sor. Ezt a konstrukciót csak a kisvállalkozói minősítésnek megfelelő, belföldi és meghatározott bevételt el nem érő adózók választhatják (tehát választható lehetőségről van szó), és a lényege, hogy az adót nem a teljesítéskor kell megállapítani, hanem akkor, amikor az ellenértéket a másik fél megfizette (az ellenértéket jóváírták, illetve kézhez vették). A törvény részletesen szabályozza a választhatóságot, a számlázást, a részletfizetést, a választásra jogosító értékhatár elemeit, valamint a lehetőség megszünését is. ${ }^{28}$

Nem minden esetben dönt azonban úgy a jogalkotó, hogy eltekint az adókötelezettség érvényesítésétöl arra az esetre, ha nem történik meg az adó tárgyát (alapját, forrását) képező ellenszolgáltatás tényleges realizálása. Az egyszerüsített vállalkozói adóról szóló 2002. évi XLIII. törvény (Evatv.) tartalmazza azt a szabályt is, amely szerint a bevétel megszerzésének időpontjának kell tekinteni a bizonylat kibocsátásának napját követő 30. napot, ha az adóalany a bevételt eddig az időpontig még nem szerezte meg. ${ }^{29} \mathrm{Ez}$ azt jelenti, hogy akkor is megszerzettnek kell tekinteni a bevételt, ha azt ténylegesen nem fizették meg az adózó számára (pl. mert késedelembe esett a kötelezett).

Az Alkotmánybíróság e szabállyal kapcsolatban kifejtette, hogy az eva önként választható adónem, és a választást megelőzően az adóalanyoknak lehetőségük van megismerni a szabályait, így a mentességi eseteket is, és ennek megfelelöen hozhatják meg a választásra vonatkozó döntésüket. Az üzleti partnerek fizetöképességének előzetes felmerése valamennyi vállalkozás esetében az üzleti kockázatot jelenti. A jogalkotó döntésétöl függ, hogy e kockázatot részben átvállalja-e az adóalanyoktól oly módon, hogy az üzleti partner fizetésképtelensége miatt behajthatatlanná váló követelések után megfizetett adót az érintett adózónál valamilyen adókedvezmény formájában figyelembe engedi venni. Mindez azonban csak lehetőség, de nem kötelezettség a jogalkotó számára. ${ }^{30}$

Bármely adónemnél felmerülhet szankcióként a késedelmi pótlék, amely akkor fizetendő, ha az adózó az adót az esedékesség időpontjáig nem fizette meg (azaz fizetési késedelembe esett). Nem kell azonban késedelmi pótlékot fizetni arra az időszakra, amelyre az adózó a késedelmét igazolta. Igazolásnak csak akkor van helye,

27 Lásd az Áfatv. 142. § (1) bekezdését.

28 Lásd az Áfatv. 196/A-196/G. §§-ait.

29 Evatv. 7. $\S(7)$ bekezdés.

30 969/E/2006. AB határozat, $A B H$ 2007, 2071. 
ha a késedelmet elhárithatatlan külső ok idézte elö. ${ }^{31}$ Ha tehát átmenetileg hiányzik az adólikviditás, akkor az adóalanynak lehetösége van kimentésre, azonban külön vizsgálandó, hogy mit jelent az „elháríthatatlanság”. A Kúria az „elháríthatatlan külső ok" fogalmát úgy határozta meg, mint olyan okot, amelyre a félnek ráhatása nincs és nem is lehet, az töle függetlenül, akarata ellenére, elháríthatatlan módon következik be. Így például ebbe a körbe sorolhatóak a természeti csapások vagy egyéb emberi tényezők (háború, embargó stb.). Nem minősíthető azonban külső elháríthatatlan oknak az üzleti partner magatartása, fizetési készségének hiánya vagy a követelés behajtására tett intézkedések elhúzódása, eredménytelensége, mivel ezek az üzleti tevékenységgel együtt járó kockázati tényezők: „A vállalkozási tevékenység körén belül előforduló, azzal együtt járó olyan tényezők, amelyekre másik adóalany nem számít, de számíthatna (pl.: szerződésszerü teljesités vitatása, fizetési hajlandóság hiánya), nem külső körülmény és nem olyan, amely bekövetkezése a fél, az adózó által elöre nem látható, vagy objektíve el nem háritható." ${ }^{32}$

A fenti példák, problémák felvázolását követően az alábbi legfontosabb következtetések fogalmazhatóak meg:

- Egyes adónemeknél az adó alanyainak különös körültekintéssel kell eljárniuk, hiszen ha az adót a likviditást biztosító, adó tárgyát, illetve alapját (forrását) képező vagyoni érték tényleges megszerzése hiányában is meg kell fizetni, akkor az adólikviditás sérülhet, illetve megszűnhet. llyen esetben az adózónak a likviditást más úton kell biztosítania (más bevételforrásokból vagy hitelműveletek útján).

- A jogalkotó fogalmazhat meg könnyítéseket azokra az esetekre nézve, ahol az adólikviditás rendszerszintü problémák okán jelentős mértékben korlátozott. Ez azonban a jogalkotó saját döntése, a jogalkotó dönti el, hogy biztosít-e könnyítést jelentő eltérő szabályokat vagy sem. Kifejezett eltérő szabály hiányában azonban e könnyítések nem alkalmazhatóak, az adóalanyoknak tisztában kell lenniük a szabályokkal, és a másik szerződő fél kiválasztásakor, illetve a szerződést biztosító mellékkötelezettségek (biztosítékok) meghatározásakor - a már említett - különös körültekintéssel kell eljárniuk annak érdekében, hogy a személyükben rejlő adólikviditást biztosíthassák.

- Az üzleti partner viselkedése nagyban befolyásolja az adólikviditást, még a legkörültekintőbb módon eljáró adózó is kerülhet olyan helyzetbe, hogy az általa megbízhatónak vélt másik fél az ellenszolgáltatást nem fizette meg, és ezáltal kénytelen az adójogi szankciókat elszenvedni.

31 Art. 166. §-a.

32 A Kúria Kfv.l.35.521/2006/9. számú ítélete. 


\section{A személyi oldal és a létminimum adómentessége}

Az adólikviditásról eddig az adótárgyak, illetve adóforrások tekintetében volt részletesen szó, azonban nem mellőzhető az adó alanyában rejlő egyes körülmények vizsgálata sem, hiszen „különbséget kell tennünk az adónem természetéből és az adóalany egyéni és vagyoni körülményeiből folyó adólikviditás között”. ${ }^{33} \mathrm{Az}$ adólikviditás értelemszerüen függ az egyének vagyoni körülményeitöl, illetve attól, hogy mennyi pénz áll rendelkezésére az adófizetési kötelezettség teljesítéséhez.

Egy sajátos aspektusát jelenti a kérdésnek, hogy a jogalkotó tehet-e bármit annak érdekében, hogy általános jelleggel is érvényre juttassa az adólikviditás követelményét (az egyéni kérelmeken alapuló fizetési könnyítéseken, mérsékléseken kívül).

E kérdés távolabbi összefüggések vizsgálatára adhat alapot, hiszen az adólikviditásnak nemcsak rövid, hanem hosszú távon is érvényesülnie kell: az adólikviditás ugyanis nemcsak egy adott időpontban, egyfajta pillanatfelvételként vizsgálható, hanem gondoskodni kell annak fenntarthatóságáról, tartózkodnia kell az adóztató hatalomnak attól, hogy veszélyeztesse az adólikviditás fennmaradását. Ahogyan arra Mária Terézia is rámutatott: „[e]tetni kell a juhot, ha nyírni akarjuk”, amely megállapítással egyúttal lényegében összefoglalta a személyi adólikviditás biztosításának alapvető követelményét is. (E követelménynek megfelelően szabályozta 1767-ben a jobbágyok terheit.) Vagyis nem szabad túlzott mértékű elvonást semmilyen módon - akár likvid, akár illikvid módon - megvalósítani. Ebből adódóan szükséges a természetes személyek egy olyan anyagi bázisának a meghatározása, amelyet az adóztató hatalom nem terhelhet, tekintettel arra, hogy ez biztosítja a természetes személy létének alapját, és azt, hogy képes lesz a jövőben is jövedelem- és vagyonszerzésre (azaz adóköteles tevékenységek végzésére).

A létminimum adómentességének elve azon az elvi jelentőségű kérdésen alapul, hogy biztosítani kell-e az adóalanyok esetében a minimális megélhetéshez szükséges jövedelem adómentességét vagy sem. Ahhoz, hogy e kérdés megválaszolható legyen, elsődleges jelleggel a létminimum fogalmát és föbb problémáit kell meghatározni.

Ercsey Zsombor rámutatott arra, hogy a létminimum nem objektív kategória, a tartalma az adott társadalom kultúrájától és értékeitől, valamint politikai kompromiszszumoktól függ. Ezen túlmenően befolyásolja az egyén életkora és családi helyzete (az egyedülállókra és családokra eltérő értékek vonatkozhatnak). „A létminimum és a társadalmi minimum olyan értékösszegek, amelyek számokban fejezik ki a szükséglet-kielégítés minimális, társadalmilag még éppen elfogadható szintjét."34 Földes Béla megfogalmazta, hogy az adószolgáltatás csak az ún. szabad jövedelemböl teljesíthető, vagyis abból a jövedelemből, amely az adóalany életfenntartási költségeinek levonását követően megmarad, az életfenntartási költségek feltétlenül biztosítandók. „Ebböl pedig szükségkép következik azon elv, hogy minden jövedelem, melyböl alig vagy épen csak az élet fentartására telik, egyenes adóval annál kevésbé terheltessék, minthogy az ily jövedelmek a fogyasztási adók után amugy

33 BaLÁs (1934): i. m., 214.

34 ERCSEY Zsombor: A létminimum adómentessége Magyarországon. Jura, 2012/2, 37. 
is, és néha elég jelentékenyen és aránytalanul, az állam kiadásaihoz hozzájárulnak. A létminimum adómentességét pénzügy-technikai körülmények is javalják, a mennyiben ezen jövedelmek nyilvántartása nagy nehézséggel és költséggel jár." 35 Navratil Ákos a létminimum adómentességét az arányosság követelményének egyik részelemeként határozta meg, és rámutatott arra a sajátosságra, hogy a fogyasztást terhelő adók alól nem lehet mentesülni, melyek a kevés jövedelemmel rendelkezőket arányait tekintve jobban terhelik. ${ }^{36}$ Mariska Vilmos foglalkozott a létminimum adómentességének elvét elutasító érvek indokaival is, melyek szerint egyrészt a hozzájárulás mértéke lehet rendkívül csekély (szimbolikus is), másrészt pedig az állami müködés a nélkülözhetetlen javak körébe tartozik, és így a fenntartására fordított kiadás szintén a létminimumhoz sorolandó. „Még a legkisebb jövedelemre utalt polgár sem fog éhen halni, ha jövedelmének aránylag is nagyon csekély részét, pl. 1\%-át az államnak engedi át, s ez által polgári kötelességét teljesíti. [...] lgazságos tehát, hogy valami csekélységgel, pl. évenkint egy napi munkabérrel, még a legutolsó munkás ember is hozzájáruljon az állam fennállásához." ${ }^{37}$

Szükséges annak a rögzítése is, hogy a létminimum adómentessége elsődleges jelleggel a magánszemélyek esetében és a jövedelemadóknál merülhet fel, viszont például a fogyasztást terhelő adók vonatkozásában nem értelmezhető, hiszen az ilyen típusú adók a létminimumot is terhelik. Az is fontos további jellemzője a kérdésnek, hogy a létminimum függ az életszínvonaltól, mást jelenthet országonként, de egy adott országon belül is. ${ }^{38}$

A fentieket összegezve megállapítható, hogy a létminimum adómentessége és az adólikviditás kérdése kapcsolódik egymáshoz. Az adóalanyok közvetlen megélhetési költsége okvetlenül biztosítandó, adót pedig tényleg csak „szabad jövedelemböl” lehet teljesíteni. Hogy mekkora a létminimum mértéke, az viszont kérdéses: a közvetlen fizikai létezést lehetővé tevő dolgokon, szolgáltatásokon kívül milyen egyéb tényezők sorolhatóak ebbe a körbe? E kérdés megválaszolása összetett feladat, azonban mindenképpen megfontolandó Mariska Vilmos azon gondolata, amely szerint a közös terhek finanszírozásához - akár csak a legcsekélyebb, adott esetben szimbolikus mértékben is - mindenkinek valamilyen módon hozzá kell járulnia. Mindez a közszolgáltatások értékének tudatosulását is eredményezheti, még akkor is, ha adott esetben a közszolgáltatások mennyisége, színvonala fejleszthető lenne. Ezen túlmenöen, ha a létminimum körébe sorolják az adófizetési kötelezettségek teljesítését is, akkor ezen összeggel az „egyszerű létminimum” értéke emelkedik, és így elegendő mértékű fedezet állhat rendelkezésre az adókötelezettség teljesítéséhez, a személyi adólikviditás biztosítható.

35 Földes Béla: Társadalmi gazdaságtan. Athenaeum Irodalmi és Nyomdai R.-Társulat, Budapest, 1907, $436-437$.

36 NAVRATIL Ákos: A társadalmi gazdaságtan és a közháztartástan vázlata. Grill Károly Könyvkiadó Vállalata, Budapest, 1908, 280-281.

37 MARISKA: i. m., 110.

38 FeLLner Frigyes: Adótehermegoszlás. Budapesti Statisztikai Közlemények, 79/3, 287-288. 


\section{Az illikvid adóztatás következményei}

Balás Károly Shylock ${ }^{39}$ esetéhez hasonlítja azt, ha az adóztató hatalom lehetetlent kér az adóalanyoktól. A példa azt illusztrálja, hogy az adóalanyban rejlö adózási képesség szenvedhet sérelmet, végső soron a jövőbeli adózási képesség meg is semmisülhet: „Felesleges is talán említeni, hogy az illikvid adókövetelés nemcsak pénztári bevételcsökkenésben érezteti a hatását, hanem ennél sokkal mélyebben rejlő bajokat is jelent, mert behajtásának eröltetése tönkreteszi az adómorált meg az adófizetési akaratot és szinte önsegélyként való szabotálást von maga után. A nem likvid adóforrásból jelentékenyebb pénzbeli adómennyiséget kivenni nem lehet. A pénzbeli adóösszegek elöteremtéséhez ugyanis vagy az adóforrás tiszta hozadékának, vagy magának az adóforrásnak pénzrecserélése szükséges. [...] nem likvid adóforrás után jelentékeny mértékü adót (pl. vagyondézsmát s általában a hozadékméreteket túlhaladó bármily adónemet) követelni shylocki eljárás, mely lehetetlenséget követel az adóalanytól. Az adóalany ilyenkor ugyanis bármily áron kénytelen az adótárgyat elkótyavetyélni vagy átengedni, hogy a kincstár szoritásától megmeneküljön." ${ }^{\prime 40}$

Az adóztató hatalomnak mindig figyelembe kell vennie az adólikviditás kérdését. Arra is van azonban lehetősége, hogy az adólikviditás követelményével visszaélve azt a gazdasági háború eszközévé tegye. Példaként említhető a két világháború közötti időszakból a csehszlovák vagyondézsma, amikor is „egyes falhozszoritott birtokosok a kiszabott vagyondézsma összegével szemben illikvid adóforrásukat, a földet nem birták megtartani, mert az adó összege kifizethetetlen volt az illető földbirtokból, mint pénzhozadéki forrásból. Ennélfogva minden felkínált áron tul kellett rajta adniok és pedig igen gyakran az állam javára. Ezt az eljárást semmiféle adóetika nem engedheti meg és legfeljebb azzal magyarázható az, hogy éppen bizonyos tulajdonoskategóriák kiirtásának céljait szolgálta. Ilymódon az adólikviditás követelményeivel való visszaélés a gazdasági háború eszközévé tehetö igen könnyen." ${ }^{41}$

Ugyancsak az illikviditásra épülő szemléletmód jellemezte a rendszerváltást megelőzően - az ideológiai környezetnek megfelelően - a magyar illetékrendszert. A vagyonszerzés, az ajándék és az öröklés illetékterhei ugyanis megemelkedtek, a progresszivitás erősödött. ${ }^{42}$ Ennek megfelelően nem meglepő, hogy az 1986. évi I. törvény a nagyobb értékü örökségre, illetve ajándékra még gyermek-szülő viszonylatban is $40 \%$-os, míg rokoni kapcsolatban nem állókra $60 \%$-os illetékmértéket állapított meg. Ilyen kulcsok mellett csak a legritkább esetben lehetett megfizetni a megszerzett vagyon részbeni vagy teljes értékesítése (likvidálása) nélkül a kiszabott illetéket.

39 William Shakespeare „A velencei kalmár” címü darabjában az uzsorás, Shylock úgy ad kölcsön Bassaniónak, ha a barátja, Antonio úgy vállal kezességet nemfizetés esetére, hogy egy font húst vághat ki belöle (azaz az életével fizet). A követelés érvényesítése azonban más életének kioltásával járt volna. Lásd FERGUSON, Naill: A pénz felemelkedése. Scolar Kiadó, 2010, 37.

40 BaLÁs (1934): i. m., 212.

41 Balás (1934): i. m., 213.

42 Herich György: Adótan I. Penta Oktatási Centrum, Pécs, 2004, 25. 


\section{Jogintézmények és jogi technikák az adólikviditás biztosítása érdekében}

1. Az adóhalasztás. Az adóhalasztás akként határozható meg, hogy az adóztató hatalom átmenetileg lemond az adó megfizettetéséröl, viszont az adóalany később köteles - adott esetben kamatokkal együtt - az adó megfizetésére. Az adóhalasztást érdemes elhatárolni a fizetési könnyítésektöl (fizetési haladéktól), tekintettel arra, hogy egyrészt az adóhalasztást magukban foglaló jogszabályok kifejezetten jogalkotói kezdeményezésen alapulnak (jogszabály nevesíti ezt a lehetőséget), másrészt pedig, hogy az adóhalasztással érintett személyi kör pénzügyi helyzete nem átmenetileg, hanem tartós mértékben olyan, hogy az adóalany nem képes megfizetni az adót, és a jogalkotó nem várja el tőle, hogy az adó összegét oly módon teremtse elő, hogy az adótárgyat elidegenítse. (Az adóhalasztás nem tételesjogi fogalom, a kategória egymástól függetlenül szabályozott, hasonló tartalmú jogintézmény öszszefoglalására használható elméleti kategória, amely nem azonos a fizetési halasztással, amely kifejezetten a fizetési könnyítések egyik esete az adózás rendjéről szóló törvényben.)

Az adóhalasztásra egyik példa lehet a magyar rendszerben adófelfüggesztés elnevezéssel illetett jogintézmény, amely a vagyoni típusú helyi adóknál nyert ilyen néven szabályozást. Az adófelfüggesztés nem eredményezi az adóteher alóli végleges mentesülést, pusztán időben kitolja annak realizálását. Ugyancsak létezik adófelfüggesztés a jövedéki adók területén, amely azt jelenti, hogy ameddig a jövedéki termék az adóraktárban van, addig nem kell utána az adót megfizetni. Mindez ugyancsak összefüggésben áll az adólikviditással, hiszen az adó megfizetése az adóalanyok által az adófizetési képességük függvényében tervezhető.

Az adóhalasztásra másik példa lehet az a feljebb említett és tárgyalt kedvezmény, amely az öröklési illeték esetében a kiskorú által megszerzett örökség tekintetében érvényesíthetö. A jogalkotó feltételezi ebben az esetben a pénzszolgáltatási képesség korlátozott voltát, illetve hiányát, hiszen lehetséges, hogy a hagyatékban az illetékfizetési kötelezettség teljesítéséhez elegendő pénz is található, azonban ez nem törvényszerü, a jogalkotó ezt a körülményt pedig az egyedi esetekben nem kívánja vizsgálni, így a kedvezmény a kiskorú örököst a törvény erejénél fogva megilleti.

2. Az adómentesítés. Az adólikviditás szempontjából külön vizsgálható az adómentesítés kérdése. Az adómentesítés alatt az értendő, amikor az állam valamely összeg után lemond az adóztatásról. Ebben a körben kell vizsgálni a létminimum adómentességét, amelyet korábban adójóváirásként szabályoztak a magyar személyi jövedelemadóról szóló törvényben.

A jogalkotó ezt teheti annak ellenére is, hogy a jövedelem az egyik leglikvidebb adótárgy. Azonban ahhoz, hogy az adóalany megörizhesse jövedelemtermelö és így adózás tárgyát képező tevékenységét, szükség van arra, hogy az adóalany rendelkezzen az alapvető megélhetéséhez szükséges pénzügyi feltételekkel, és e feltételeket az adóztató hatalom ne korlátozza azzal, hogy az adóteher érvényesítése által a létminimum alá szorítja az adóalany pénzügyi forrásait.

Szükséges annak az ismételt rögzítése is, hogy a létminimum adómentessége elsődleges jelleggel a magánszemélyek esetében és a jövedelemadóknál merülhet 
fel, viszont például a fogyasztást terhelő adók vonatkozásában nem értelmezhetö, hiszen az ilyen típusú adók a létminimumot is terhelik. Az is fontos további jellemzője a kérdésnek, hogy a létminimum függ az életszínvonaltól, mást jelenthet országonként, de egy adott országon belül is. ${ }^{43}$

3. Az adóelölegeztetés. Az adóelöleg önmagában is alkalmas lehet az adólikviditás mértékének megörzésére, fokozására. Ha nem egy összegben kell ritkábban (évente egyszer) megfizetni egy nagyobb mértékü összeget, akkor nem áll fenn a veszélye annak, hogy az adózó időközben - akár tudatosan, akár nem megfelelő tervezésből adódóan - elveszíti a teljesítéshez szükséges pénzt. Az adóelölegeztetés tehát az adólikviditás szempontjából is fontos lehet, nemcsak az államháztartás bevételeinek folyamatossága érdekében alkalmazható megoldás.

Ha az adóelöleghez levonási kötelezettség is kapcsolódik a kifizető (a munkáltató) részéről, azzal az adólikviditás teljes körüen érvényesülhet, hiszen nincs lehetöség arra, hogy az adózó az adó összegét elvonja, hiszen nem is rendelkezhet vele.

4. Az adólevonás. Az Art. adókötelezettségként nevesíti az adólevonást, egyes anyagi adójogi törvények - így például a személyi jövedelemadóról szóló törvény - különböző jövedelmek esetében elöírja a levonási kötelezettség alkalmazását. A levonás nemcsak az adózók szempontjából jelenthet adminisztratív tehermentesítést, hanem lehetövé teszi, hogy a pénzben realizált értékböl rögtön elkülönítésre kerüljön az adó összege. Így például ha a törvény a kamatadó tekintetében adólevonási kötelezettséget állapít meg a pénzügyi intézmény terhére, akkor az adó összege rögtön rendelkezésre is áll, az idő elörehaladtával nem kerülhet veszélybe az adólikviditás. Másfelöl az adózónak nem kell külön az adót megállapítania, illetve bevallania, így a levonás ebböl a szempontból is hasznos eszköz.

5. Az adó átháritása. Az áthárítható, illetve közvetett adók alkalmazása szintén komoly jelentőségủ eszköz. Ilyen esetben az adóalanynak eleve rendelkeznie kell az adó összegével is, ellenkező esetben nem képes az adótényállás megvalósítására (például az általános forgalmi adóval terhelt - és az adót is tartalmazó árú terméket nem képes a természetes személy megvásárolni, ha a teljes, az általános forgalmi adóval számított vételárral nem rendelkezik). Az adótárgyhoz kapcsolódó pénzösszeg ilyenkor az adó alanya részére megfizetésre kerül az adót ténylegesen viselő vásárló részéről. Az adóáthárítás azonban csak akkor biztosítja az adólikviditás érvényesülését, ha a két fél részéről nem válik el időben egymástól a szerződés teljesítése, hiszen a fizetési határidő mellett kibocsátott számla esetében fennáll a veszélye annak, hogy bár az eladó (vállalkozó stb.) részéröl a teljesítés megtörtént, nem feltétlenül fog hozzájutni az ellenszolgáltatáshoz, és így az adó összegéhez. E probléma kezelésére merülhet fel a következő pontban megnevezett eszköz, az adóalanyváltás alkalmazása.

6. Az adóalanyváltás. Ha az adott adónem attól függetlenül is terheli az adóalanyt, hogy az adó alapját képező vagyoni értékhez (például a számlán rögzített ellenszolgáltatáshoz) nem jutott hozzá, akkor óhatatlanul előállhat az a helyzet, hogy az adólikviditása önhibáján kívül sérül. Fő szabály szerint azonban ilyen esetben sem mentesülhet az adó megfizetésének kötelezettsége, illetve a késedelemhez kapcso-

${ }^{43}$ Ismételten hivatkozva FELLNER: i. m., 287-288. 
lódó jogkövetkezmények (szankciók) alól. A jogalkotó döntésétől függ, hogy alkalmaz-e olyan jogintézményeket, amelyek segíthetnek azon adóalanyoknak, amelyek olyan szektorokban tevékenykednek, ahol tömegesen fordulnak elő nemfizetések, lánc-, illetve körbetartozások. Az áfa esetében ilyen például a fordított áfafizetési kötelezettség meghatározása egyes esetekben, ami azt jelenti, hogy mentesítik az adó alanyát a nemfizetésből adódó kockázat alól oly módon, hogy a másik felet kötelezik az adó megfizetésére.

7. Az adótürelem. Az előző pontban említett probléma kezelésére alkalmazható megoldás az adótürelem, amely azt jelenti, hogy a jogalkotó megvárja, amíg az adózó hozzájut az adó megfizetését lehetővé tevő értékhez, és ezáltal az adólikviditás biztosan bekövetkezik. llyen jogintézmény például a feljebb részletesebben tárgyalt pénzforgalmi elszámolás az áfa esetében, amely azt jelenti, hogy vizsgálandó az ellenérték tényleges kézhezvétele: ha rendelkezésre áll az összeg, akkor kell az adóalanynak a hozzá kapcsolódó adóterhet ténylegesen megfizetni.

8. Szociális, gazdasági szempontok figyelembevétele a jogalkotás során. A helyi adókról szóló törvény általános korlátként rögzíti a települési önkormányzatok esetében, hogy az adómegállapítási joguk gyakorlásakor - az adó mértékének meghatározásakor - figyelembe kell venniük a helyi sajátosságokat, az önkormányzat gazdálkodási követelményeit és az adóalanyok teherviselö képességét. E követelmény általános jellegü, kikényszeríthető tartalommal nem bíró előírásnak tủnik, azonban - a feljebb tárgyaltak szerint - mind az Alkotmánybíróság, mind pedig a Kúria a gyakorlatában komoly jelentőséget tulajdonít e szabálynak; hiába felel meg egy önkormányzati rendelet például az adómaximumra (az adó felső mértékére) vonatkozó elöírásoknak, ha egyszer a helyi adó szabályozásakor nem határoz meg megfelelő kedvezményi, mentességi eseteket.

9. Az adólikviditás feléledésének feltételezése. A közbeszerzési szerződések esetében, tehát azokban az esetekben, amikor közpénz kerül kifizetésre egy polgári jogi szerződés teljesítésének eredményeként egy gazdasági szereplő részére, lehetőség nyílik arra, hogy a kifizetésre jogosult gazdasági szereplő az adótartozását rendezze. Az Art. szabályozza ennek megfelelően a visszatartásra vonatkozó szabályokat: ha a kifizetésre jogosult nem tudja igazolni, hogy nincs köztartozása, akkor vissza kell tartani az ellenértéket abból a célból, hogy az adóhatóság a fennáló adótartozást behajthassa a kifizetendő ellenérték terhére. (Azaz a kifizetőnek vissza kell tartania az ellenszolgáltatást, hogy az adóhatóságnak legyen lehetősége a végrehajtásra. $)^{44}$

Ilyen esetben a jogalkotó nem tesz mást, mint a korábban nem teljesítő adóalany likviddé válását használja fel: az adólikviditás azáltal következik be, hogy ténylegesen nem jut pénzhez az adótartozással rendelkező adóalany.

A fent leírt eszközök tekinthetőek az adólikviditás biztosítása közvetett eszközei$n e k$, ugyanis ezekben az esetekben nem vizsgálják az adóalany tényleges likviditását, vagyoni és jövedelmi viszonyait; erre csak az egyénileg kezdeményezett fizetési könnyítések (mérséklések) - a közvetlen eszközök - rendszere képes. A közvetett eszközök ugyan nem biztosítják (és nem is biztosíthatják) minden esetben a teljes

${ }^{44}$ Lásd az Art. 36/A. §-át. 
körủ adólikviditást, azonban alkalmazásuk egyrészt hozzájárulhat egy megfelelöbb adórendszer kialakításához, másrészt pedig lehetővé teszik a közvetlen eszköz alkalmazásának mellőzését vagy éppen kiváltását, hiszen nem minden illikvid adózót illeti meg a fizetési könnyítés lehetösége. Ebböl adódóan különösen fontos, hogy a jogalkotó megfelelő, közvetett eszközként meghatározható jogintézményeket szabályozzon az adójogban (vagy akár más jogágakban, jogterületeken).

Ha viszont nincs speciális szabály, jogintézmény, akkor az adóalanyoknak tudatos és felelős módon kell tervezniük az adólikviditásuk biztosítását, fenntartását. Ennek eszközei lehetnek például a vásárlások, megrendelések ütemezése, a számlázás rendjének kialakítása, az adóösszeg elkülönítése, az üzleti partnerek gondos és körültekintő kiválasztása a fizetőképesség és -készség előzetes vizsgálatával vagy a megfelelő szerződést biztosító mellékkötelezettségek és biztosítékok meghatározása arra az esetre, ha a másik szerződő fél valamilyen elöre nem látható okból kifolyólag mégis fizetésképtelenné válna.

\section{Zárógondolatok}

Az adólikviditás kérdésköre vizsgálható egyrészt közgazdasági-pénzügytani, másrészt pedig pénzügyi jogi szempontból. Különösen fontos, hogy a jogalkotó az egyes adótárgyakat hogyan jelöli ki, az adóforrások képesek-e az elöírt pénzszolgáltatási kötelezettség teljesítéséhez szükséges pénzmennyiséget biztosítani, az adóalanyok képesek-e az adókötelezettségüknek oly módon eleget tenni, hogy a jövőbeli adózási képességük ne sérüljön, illetve ne semmisüljön meg. Az adójogi szabályozásban is számos olyan jogintézmény létezik, amely az adólikviditás biztosítása érdekében nyert szabályozást, a kifejezett szabályok hiányában pedig még mindig rendelkezésre állhatnak a méltányosságon alapuló fizetési könnyítések, mérséklések lehetöségei (ezek alkalmazása azonban feltételekhez kötött).

Különösen fontos lehet annak kutatása, hogy a joggyakorlat hogyan tölti meg az elvont jogszabályi fogalmakat konkrét tartalommal, hogyan ítéli meg az egyes adózói illikvid helyzeteket, mikor tagadhatja meg a jogalkalmazó a fizetési könnyítés engedélyezését, illetve a tartozás mérséklését, mikor mentesítheti az adózót a szankció alól.

Zárásképpen célszerü Balás Károly alábbi gondolatait idézni: „Az adóforrások likviditása vagy illikviditása dolgában követni való adópolitikát illetőleg az elvi kiindulásnak abból a szempontból kell történnie, amelyet már a rómaiak ekként fejeztek ki: ad impossibilia nemo teneatur. Lehetetlenséget senkitöl sem szabad követelni. Amily magától értetődőnek látszik azonban ez az alapelv pénzügyi téren is, a gyakorlatban mégis annyit vétettek már ellene." ${ }^{\prime 45}$ 


\begin{abstract}
The paper scrutinizes the definition, the general and the legal characteristics of tax liquidity. It is a very essential question as to whether taxable persons have enough money to fulfill the obligation of taxpaying, secure their abilities to pay taxes in the future. The tax liquidity can be analyzed specially in the field of duties, ordinary and extraordinary taxes of wealth and natural justice. The legislator can regulate different legal institutions to fulfill the requirement of tax liquidity: it can prescribe for example various allowances, the possibility of deduction or it can ensure different possibilities in the field of fairness.
\end{abstract}

